\title{
Evaluation of the Impact of Different Types of Uncoupling on the Processing Capacity of Hump Yards
}

\author{
Miroslava Mikusova1*, Matljuba Khajimuhamedova², Joanna Zukowska³, Tomasz Mackun³ \\ 1 Department of Road and Urban Transport, Faculty of Operation and Economics of Transport and Communications, University \\ of Zilina, Univerzitna 8215/1, 010 26, Zilina, Slovakia \\ 2 Organization of transportation and control, Tashkent Institute of Railway Transport Engineers, Adilkhodjaeva 1, 100067, \\ Tashkent, Uzbekistan \\ ${ }^{3}$ Department of Highway Engineering, Faculty of Civil and Environmental Engineering, Gdansk University of Technology, Gabriela \\ Naturowicza, 80-233, Gdansk, Poland \\ * Corresponding author, e-mail: miroslava.mikusova@fpedas.uniza.sk
}

Received: 22 May 2020, Accepted: 13 August 2020, Published online: 08 February 2022

\begin{abstract}
The paper considers the issue of evaluating the impact of different types of uncoupling to increase the processing capacity of hump yards to ensure high technical-economic indicators in the conditions of limited capital funds. Moreover it describes the mathematical formulation of the sorting slide. For the mathematical formulation, the sorting slide is taken as a surface that is uniquely projected onto a horizontal plane. Based on the results of calculations, more accurate data on the speeds of movement along the downhill part of the slide are determined. This data is compared with experimental results.
\end{abstract}

Keywords

processing capacity, uncoupling, hump yards

\section{Introduction}

The presence of hump yards in the railway transport infrastructure enables to increase the processing capacity of the points of dissolution and formation of convoys of freight trains. This is confirmed by several studies (Torok, 2019; Hokstok and Mészáros, 2011; Adamis and Mészáros, 2013; Mészáros, 2006) that were developed on this topic. When weight categories are used correctly the individual uncoupling can increase productivity by screening the slides, without using large amounts of capital (Szabó and Török, 2020). For this purpose, an analysis of the traffic volume passing through the hump was made, the most significant results of which are presented in this paper.

\section{The main problems}

In practice new ways of enhancing the processing capacity of hump yards were developed as a result of growing traffic volumes: the introduction of the second path of the thrust, the organization of parallel dissolution trains (Dudnichenko et al., 1981; Pavlov, 1970). Although these methods increase the processing capacity of hump yards they require significant initial capital expenditures (Stasiak-Betlejewska and
Torok, 2019). The organization of a parallel dissolution of the compositions of the trains requires significant additional operating costs. In this case, processing s of cars in a grading system is presented (Bessonenko, 2008).

One of the significant measures to increase the processing capacity of hump yards and ensure high technical and economic indicators in the conditions of limited capital funds is the organization of the variable speed of dissolution of the compositions of the freight trains on sorting slides (Grznár, 2003; Mikusova et al., 2019). Large quantities of uncoupling are the opportunity to increase the speed of dissolution of the compositions of the freight trains and increase the processing capacity of hump yards (Kovács and Mészáros, 2015).

At the same time, indicators of increasing the processing capacity of hump yards by the organization of the variable speed of dissolution of the compositions of the freight trains are significantly affected by the proportion of different numbers of cars in the uncoupling and spread of hump yards in the most important points of processing of cars (Sásik et al., 2016). 
At the initial stage, it is necessary to consider the value of technical and economic indicators of traffic volumes in the sorting station. For the realization of the analysis the following data was available: characteristics of the traffic volumes and the number of cars in the uncoupling on the hump. At this stage, it is necessary to assess the magnitude of traffic volumes (Callejas-Cuevo et al., 2020).

Statistics data show that in a separate uncoupling there exist significant fluctuations in the value of wagons: from 1 to 10 and more. In turn, the number of wagons in the uncoupling is significantly dependent on the number of sorting paths in the yard. So, with the increasing number of sorting ways, there appears an increasing number of appointments of plan formation. This reduces the possible number of cars in the uncoupling in the process of dissolution of the compositions at the hump yards.

Estimation of the technical and economic indicators of operation of marshalling yards and surrounding areas need to be set by statistical data and the operational performance of the marshalling yards and slides. They are set depending on the number of cars in the uncoupling formed on each of the marshalling yards, depending on the volume of operation and the number of yards or number of assignments, plan formation, taking place at the landfill rail lines.

To assess this parameter technical-economic indicators of the nature of the presence of uncoupling of various sizes for sorting station "N" the data is given in Table 1.

Various technical and economic indicators provided in Table 1 were determined by Eq. (1) (Savchenko et al., 1980).

$P_{i}=K_{i} / \sum K$,

where:

$K$ is the number of uncouplings at the respective $i$ values;

$\sum K$ the total number of uncouplings taken for analysis.

In the existing system analysis of main indicators of work of a switchyard, the sum of the probabilities is determined by Eq. (2).

$\sum P_{i}=P_{1}+P_{2}+\ldots+P_{i}$

where:

$P$ is the probability of occurrence of an uncoupling measure of corresponding value;

$i=1,2, \ldots, i$ is the number of possible values for a given technical-economic indicator.

Fig. 1 and Table 1, it can be seen that there is a small probability of the appearance of cuts of a large value in the total number in the process of their dissolution from the hump. The number of cars in the uncoupling of the corresponding value can be determined according to the Eq. (3) (Savchenko et al., 1980).

$\sum B=n_{\mathrm{unc}} \cdot n_{\mathrm{unc}}^{\mathrm{car}}$,

where:

$n_{\text {unc }}$ is the number of uncouplings at the corresponding values;

$n_{\mathrm{unc}}^{\mathrm{car}}$ is the number of uncoupled cars/The total number of cars cumulatively equals to:

$\sum B_{\text {total }}=B_{1}+B_{2}+\ldots+B_{\kappa}$,

where:

$B$ is the possibility of the number of cars in the uncoupling of the corresponding value;

$K=1,2, \ldots, K$ is the cumulative number of cars in the uncoupling.

The nature of values of the corresponding indicators as indicators of the operation of hump yards or the number of wagons are shown in Fig. 2.

The data in Table 1 showed that when the hump is uncoupling, the most likely scenario is the appearance of 1 and 2 cars in the cut. Cuts of 4-5 wagons have a low probability. And also, there are cuts of 10 or more cars.

Table 1 Characteristics depending of the number of cars in trailers

\begin{tabular}{lccccc}
\hline $\begin{array}{l}\text { The number } \\
\text { of wagons } \\
\text { un-hooked }\end{array}$ & $\begin{array}{c}\text { The } \\
\text { number } \\
\text { of values }\end{array}$ & $\begin{array}{c}\text { The } \\
\text { probability }\end{array}$ & $\begin{array}{c}\text { The } \\
\text { sum of } \\
\text { probabili- } \\
\text { ties }\end{array}$ & $\begin{array}{c}\text { The } \\
\text { number } \\
\text { of } \\
\text { wagons }\end{array}$ & $\begin{array}{c}\text { The } \\
\text { number of } \\
\text { wagons on } \\
\text { an accrual } \\
\text { basis }\end{array}$ \\
\hline 1 & 47 & 0.47 & 0.47 & 47 & 47 \\
2 & 19 & 0.19 & 0.66 & 38 & 85 \\
3 & 10 & 0.10 & 0.76 & 30 & 115 \\
4 & 10 & 0.10 & 0.86 & 40 & 155 \\
5 and more & 14 & 0.14 & 1.0 & 140 & 295 \\
TA total & 100 & 1 & & 295 & \\
\hline
\end{tabular}

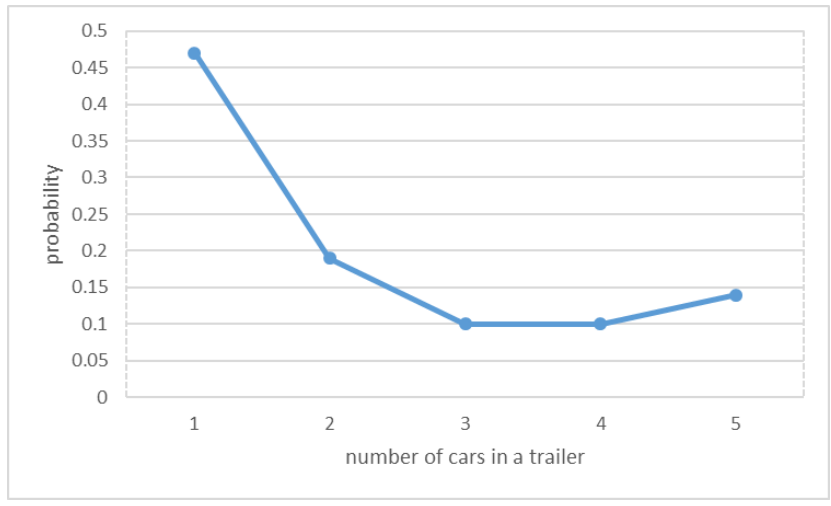

Fig. 1 Probability of different numbers of cars in the train 


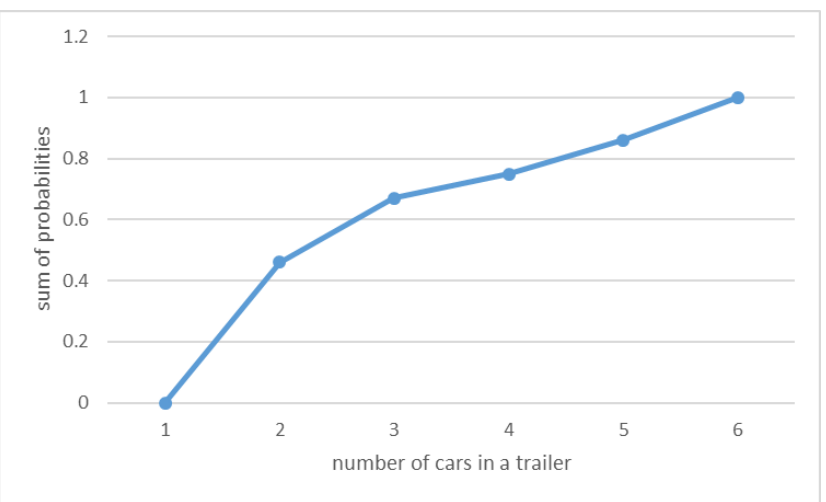

Fig. 2 Change in the total number of cars depending on their size

Statistics data shows that the nature of the cumulative change of the performance of the stations and the number of possible uncoupling are depending on the number of cars. Fig. 2 shows that a small number of cars in cuts takes the maximum share in their number. The further construction of hump yards almost does not increase the total probability of their occurrence.

Rational designs of hump yards, their performance, as well as the height of hump yards are significantly affected by the presence of cars with different weight characteristics to dissolve the compounds of freight trains. Thus, the existing scientific literature provides a classification of cars by weight, the categories of which are characterized as (VBR), (BR), (GR), and (VGR). For a very bad runner (VBR) a 4-axle gondola car on roller bearings weighting $22 \mathrm{t}$ is taken, for a bad runner (BR) a 4-axle gondola car on roller bearings weighting $25 \mathrm{t}$ is taken, for a good runner (GR) a 4-axle wagon weighing $70 \mathrm{t}$ is taken, and for a very good runner (VGR) a 4-axle wagon weighing $85 \mathrm{t}$ is taken (Borodin et al., 2002).

The magnitude of hump yards, their performance, and the operating costs associated with the upsetting of wagons in the marshalling bay have a significant negative influence in the case of the presence of light cars (VBR and BR). These cars cover short distances in the case of uncoupling at the hump. Consequently, it is necessary to increase the height of hump yards, which causes a significant increase in capital costs in their construction. Also, there is a need for the inhibition of a large number of traction vehicles of cars, causing a significant increase in CapEx and higher operating costs.

The maximum height of the hump is set for very bad runners (VBR) or empty cars that feature a poor performance and fail to reach the desired point in the marshalling bay. As a result, "windows" are formed on the sorting tracks between the cuts. This causes the need for a special separation of wagons in the marshalling bay and the growth of operating costs associated with the processing of wagons in the marshalling bay (Mukha and Yanemic, 1974).

The nature and magnitude of technical and economic indicators of operation of hump yards are significantly affected by the presence of uncoupling including a few cars. If there are multiple cars in the uncoupling there appears the possibility of increasing the performance of hump yards due to the following peculiarities of the technology of wagon processing points at the major marshalling yards:

a) sorting the tracks with a smaller number of available spaces, thereby reducing the likelihood there is a smaller need to have the cost of shunting means for implementing separation of wagons in the marshalling bay;

b) the possibility appears increasingly in case of implementing a variable speed of dissolution of the cars, which will increase the processing capacity of hump yards;

c) smoothing the weight of individual cars.

These factors affect the appearance of light cars and the likelihood of uncoupling of different sizes or different categories.

To study the impact of the number of cars in the uncoupling on the operational performance of the hump yards in stages the following work was conducted:

a) at the initial stage, all single cars were dismissed with hump yards' single order;

b) a single uncoupling was composed of a different number of cars.

The study of this techno-economic measure was implemented separately for cars and empty areas. To assess the technical and economic indicators, the possible intervals in the weight of the wagons were taken separately for the loaded and the empty directions. The study was conducted with a weight interval of 10 tons, more specifically from 20 to 90 tons on the car.

In total, 150-200 values of the frequency of occurrence or the probability of occurrence of the weight of individual cars of the most varied size were taken for the research. The analysis covered up to 300 different quantities of uncoupled cars from the hump. In total 300 individual physical cars were implemented in the modeling of process of formation of uncoupling for the various configurations.

The research process was conducted in the following order: 
a) at the beginning, in one day, the cuts were released from the hump according to the existing configuration of the number of cars in the cut;

b) the probability was set for a given traffic volume of the individual weight values of the cars.

By building a tabular dataset the probability of the weight of uncoupling of various sizes was detected. The effect of the possible number of cars in a cut or oscillation of cars in a cut on the likelihood of the appearance of cuts of the most different weight in the process of breaking up cars from the hump was established. For individual physical wagons, the weight was determined according to the data of the invoice documents or according to the weight indicated in the full-scale sheet, using Eq. (5).

$q_{\text {gross }}^{\text {unc }}=\sum q_{\text {gross }}^{\text {unc }} / n_{\text {car }}^{\text {unc }}$,

where:

$\sum q_{\text {gross }}^{\text {unc }}$ is the total weight of all wagons sent from the marshalling yard in the direction in question per day;

$n_{\text {car }}^{\text {unc }}$ is the total number of all cars sent from the marshalling station in the direction in question per day.

At the initial stage, the probability of the average weight of individual groups of wagons was established, taking into account the number of wagons in the trains.

The data in Table 2 show that, in the presence of cutoffs opened from the sorting slides, indicators of small and heavy weight are more common for existing conditions.

Initially, the study was conducted for the freight direction. For this direction the average weight of individual wagons was established by Eq. (6). (Savchenko et al., 1980)

$q_{\text {average }}^{\text {cargo }}=\sum P_{\text {departure }}^{\text {daily }} / \sum n_{\text {total }}$,

where:

$\sum P_{\text {departure }}^{\text {daily }}$ is the total weight of all wagons sent from the marshalling yard in the direction in question per day;

$\sum n_{\text {total }}$ is the total number of couplings sent from the sorting hill on the considered day.

For the considered day at station "N", the average number of cars in a train turned out to be 3 .

In total, 93 cut-offs were disbanded from the sorting hill over the course of the day under consideration at the station. The average number of cars in a train turned out to be 3 cars. The total number of cars dismantled from the sorting slide turned out to be equal to 280 cars.

The data also showed that the most likely occurrence of the weight of individual wagons is close to the average value. However, in this case, the nature of the probabilities for individual wagons differs from the values in the presence of cut-offs consisting of several wagons.

So, for single wagons, there is a high probability of the appearance of the weight of single wagons for the largest and least weight. At the same time, for single cars, the probability of the appearance of average values of the weight of the cars turned out to be less. The nature of the effect of such a difference can be shown in Fig. 3 .

The data in Fig. 3 show that the probabilities of the appearance of an average weight in one car differ to a small extent from the values of the car weights. So, there is a surge probability in the case of small $t$ and with a full load, in the range of 85 tons.

At the same time, merging into one uncoupling several cars will lead to a drastic change in the probabilities of the weight of wagons of various sizes. In separate cuts, wagons with full and low load take place or are included. This leads to the fact that the average weight of the car averaged out. Therefore, in the presence of uncoupling they are the most probable average values. This will lead to a significant reduction of the probabilities of the smallest and largest weight per car.

Table 2 Change in weight of indicators in the individual groups of cuts in the presence of cut-offs of the most varied size

\begin{tabular}{lccc}
\hline Weight Intervals & $\begin{array}{c}\text { Number of } \\
\text { values }\end{array}$ & Probability & $\begin{array}{c}\text { Sum of } \\
\text { probabilities }\end{array}$ \\
\hline $20-30$ & 181 & 0.650 & 0.650 \\
$30-40$ & 15 & 0.055 & 0.705 \\
$40-50$ & 16 & 0.060 & 0.765 \\
$50-60$ & 13 & 0.045 & 0.810 \\
$60-70$ & 14 & 0.050 & 0.860 \\
$70-80$ & 14 & 0.050 & 0.910 \\
$80-90$ & 27 & 0.090 & 1.000 \\
Total & 280 & 1.000 & 1.000 \\
\hline
\end{tabular}

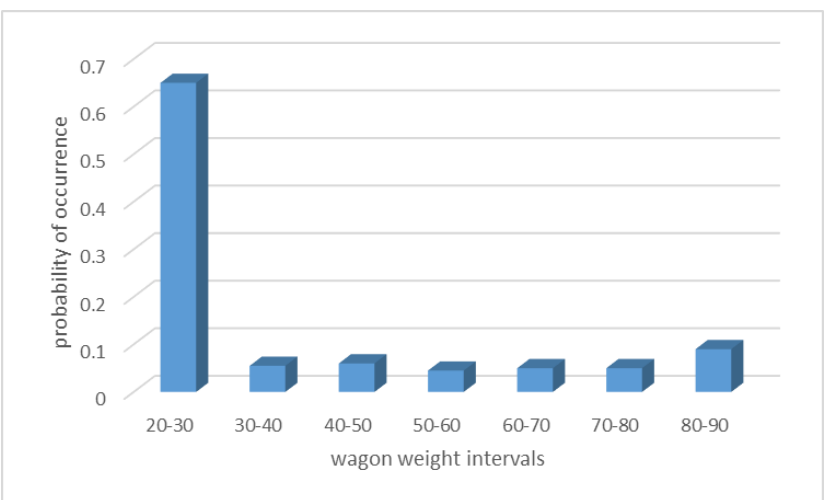

Fig. 3 Change in the probability of the appearance of unhooked cars for different wagon weight intervals 


\section{Conclusions}

The grouping or uncoupling individual cars can significantly reduce the probability of light cuts occurring for a wide variety of cut sizes. This will decrease the probability of the occurrence of the largest weight per single car. The above features lead to the fact that in the case of the appearance of cuts from several cars, the productivity of the hump will increase not only due to the possibility of organizing a variable speed of uncoupling or cuts.

\section{References}

Adamis, B., Mészáros, F. (2013) "Analysis of technological and economic conditions of co-modal freight transport chains", In: Logisztkai Évkönyv 2013, Magyar Logisztikai Egyesület, Budapest, Hungary, pp. 224-229. (in Hungarian)

Bessonenko, S. A. (2008) "Оптимизация основных параметров сортировочной горки" (Optimization of basic parameters of a gravity hump), Improvement of Operational Work of the Railways: Scientific Works of the Leningrad Institute of Transport Engineers, 160(1), pp. 4-25. (in Russian)

Borodin, A. F., Bilenko, M., Olejnik, O. A., Borodina, E. V. (2002) "Технология работы сортировочных станций" (Теchnology of the work of marshalling yards), LOTUS, Moscow, Russia. (in Russian)

Callejas-Cuervo, M., Valero-Bustos, H. A., Alarcón-Aldana, A. C., Mikušova, M. (2020) "Measurement of Service Quality of a Public Transport System, Through Agent-based Simulation Software", In: Huk, M., Maleszka, M., Szczerbicki, E. (eds.) Intelligent Information and Database Systems, ACIIDS 2019, Springer, Cham, Switzerland, pp. 335-347. http://doi.org/10.1007/978-3-030-14132-5_27

Dudnichenko, A. M., Skaballanovich, V. S., Nefedov, T. A., Sawicki, G. А. (1981) "О регулировании скорости роспуска составов на сортировочных горках" (On the regulation of the speed of dissolution of the compositions on sorting slides), VNIIZHT Scientific Journal, 103(2), pp. 11-16. (in Russian)

Grznár, P. (2003) "Tools for continual process improvement Simulation and benchmarking", In: Annals of DAAAM for 2003 \& Proceedings of the 14th International DAAAM Symposium: Focus on Reconstrucion and Development, Sarajevo, Bosnia and Herzegovina, pp. 136-140.

Hokstok, C., Mészáros, F. (2011) "Review of situation in domestic regional rail transport and vehicle procurement based on energy efficiency and environmental aspects", Közlekedéstudományi Szemle, 2011(2), pp. 43-50. (in Hungarian)

Khadjimukhametova, M. A. (2020) "Optimization of the sorting hill profile to speed up rolling of cars of various categories with the highest speed", Asian Journal of Research, 1-3, pp. 336-345. https://doi.org/10.37057/2433-202x-2020-1-6-37

Kovács, A., Mészáros, F. (2015) "Transport Economics", Széchenyi István Egyetem, Győr, Hungary. (in Hungarian)

Improving the performance of hump yards may be achieved also due to the significant reduction in the lightest cars, limiting the processing capacity of hump yards, especially under adverse conditions.

\section{Acknowledgement}

This paper was supported by the Project 586292-EPP2017-1-PL-EPPKA2-DBHE-JP - INTRAS - Intelligent Transport Systems: New ICT-based Master's Curricula for Uzbekistan, co-funded by the ERASMUS+ scheme under grant agreement n. 2017-3516/001-001.

Mészáros, F. (2006) "Developing a coherent European approach to the evaluation of transport projects", Közlekedéstudománayi Szemle, 6(1), pp. 18-21. (in Hungarian)

Mikusova, M., Callejas-Cuervo, M., Valero-Bustos, H. A., AlarcónAldana, A. C. (2019) "Integration of Simulation Techniques: System Dynamics and intelligent Agents Applied to a Case Study". In: Nguyen, N. T., Chbeir, R., Exposito, E., Aniorté, P., Trawiński, B. (eds.) Computational Collective Intelligence, ICCCI 2019, Springer, Cham, Switzerland, pp. 510-517. https://doi.org/10.1007/978-3-030-28374-2_44

Pale, A. M., Bozhko, N. P., Egorov, A. A., Mucha, Y. A., Yanevich, V. Z. (1974) "Скорости соударения отцепов и «окна», образующиеся на путях сортировочного парка" (Velocity of uncoupling, and the "window" formed in the ways of a car yard), The issues of mechanization and automation of the sorting process at stations, 160(8), pp. 98-103. (in Russian)

Pavlov, V. Е. (1970) "Особенности процесса роспуска состава на горке с переменной скоростью" (Features of the process of dissolution of the composition on the slide with variable speed), Scientific Works of the Leningrad Institute of Transport Engineers, 96(3), pp. 61-70. (in Russian)

Sásik R., Haluška M., Madaj, R., Gregor, M., Grznár, P. (2016) "Development of the Assembly Set for the Logistic Transport Solution", In: Dynybyl, V., Berka, O., Petr, K., Lopot, F., Dub, M. (eds.) The Latest Methods of Construction Design. Springer, Cham, pp. 81-86. https://doi.org/10.1007/978-3-319-22762-7_13

Savchenko, I. E., Zemblinov, S. V., Strakowski, I. (1980) "Железнодорожные станции и узлы"(The Railway station and the nodes), Transport, Tashkent, Uzbekistan. (in Uzbek)

Stasiak-Betlejewska, R., Török, Á. (2019) "Creating Safe and Competitive Conditions for the Provision of Rail Transport Services", System Safety: Human - Technical Facility - Environment, 1(1), pp. 653-660. https://doi.org/10.2478/czoto-2019-0083

Szabó, Z., Török, Á. (2020) "Spatial Econometrics - Usage in Transportation Sciences: A Review Article", Periodica Polytechnica Transportation Engineering, 48(2), pp. 143-149. https://doi.org/10.3311/PPtr.12047 
Torok, A. (2019) "Transport infrastructure role in climate resilience: A case study in Hungary", International Journal for Traffic and Transport Engineering, 6(2), pp. 188-195.

https://doi.org/10.7708/ijtte.2016.6(2).06
Uzbekiston Temir Yullari "Materials about stations of JSC", [online] Available at: https://www.railway.uz/ru/gazhk/kontaktnaya informatsiya/ [Accessed: 17 January 2020] 